\title{
Zaha Hadid:
}

Gordana Fontana-Giusti

The news of Zaha Hadid's passing away came as a shock. This kind of tremor often registers for good the place where the news reached us. It caught me on the Strand in London in an email from a former Chinese student, who was checking the news with me. Besides it feeling strange to be referred to as an unlikely authority on matters of life and death, the news appeared truly unbelievable and clearly shook this young, hardworking, and downto-earth woman architect from Xi'an in Shaanxi Province. Such was the outreach of Zaha's presence and the force of her aura that it was almost impossible to imagine her departure. Unconsciously, we maintained that Zaha Hadid would somehow, like her buildings, stay in this world for a very long time. As more broadcasters joined the fugal cacophony of reporting, the statement spread across the globe in numerous scripts and languages stating that Zaha Hadid had died suddenly from a heart attack at a hospital in Miami, Florida, where she was being treated for bronchitis.

The life of this world-leading architect began on 31 October 1950 in Baghdad, where she was born to a well-to-do internationally and multi-culturally oriented Arab family. Zaha Hadid's father, Muhammad al-Hajj Husayn Hadid, a co-founder of the left liberal political party and of the National Democratic Party, was originally from Mosul. So too was her mother Wajiha al-Sabunji, an artist who was probably responsible for Zaha's interest in drawings, design, and artistic endeavours. The couple had their daughter educated at boarding schools in Europe during the 1960 s. In one of her many interviews, Hadid mentioned that

\section{0-2016}

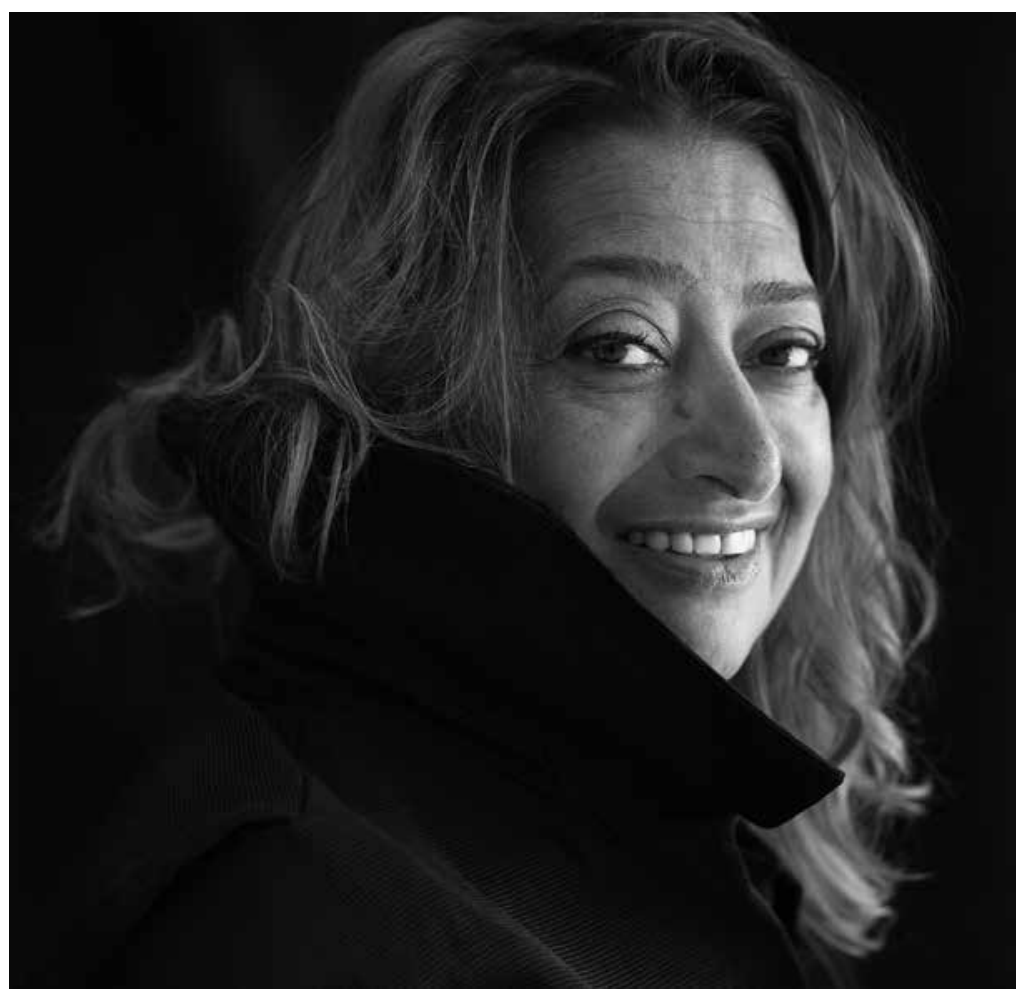

1 Zaha Hadid

her interest in architecture had its roots in her early childhood and family occasions such as a trip to the ancient Sumerian cities of southern Iraq. Hadid's family later left Iraq after the rise of Saddam Hussein and the outbreak of war with neighbouring Iran.

Initially, Zaha Hadid studied mathematics at the American University in Beirut, Lebanon, before moving to London in 1972 where she continued her education at the Architectural Association School of Architecture (AA). In that school, she met Rem Koolhaas, Elia Zenghelis, and Bernard Tschumi among others. She also taught at the AA for many years, remaining close to the school throughout her life. For a while, Hadid worked for her former tutors Koolhaas and Zenghelis, at the Office for Metropolitan Architecture (OMA) in Rotterdam, the Netherlands, becoming a partner in 1977. Hadid held the Kenzo Tange Professorship at Harvard Graduate School of Design where she taught in the mid-1980s. She started her own London-based practice in 1980 and became a naturalised subject of the United Kingdom.

Hadid's trademark prominent self-belief and strength could be traced back to her early life. She recalled how her childhood opinions concerning fashion, 


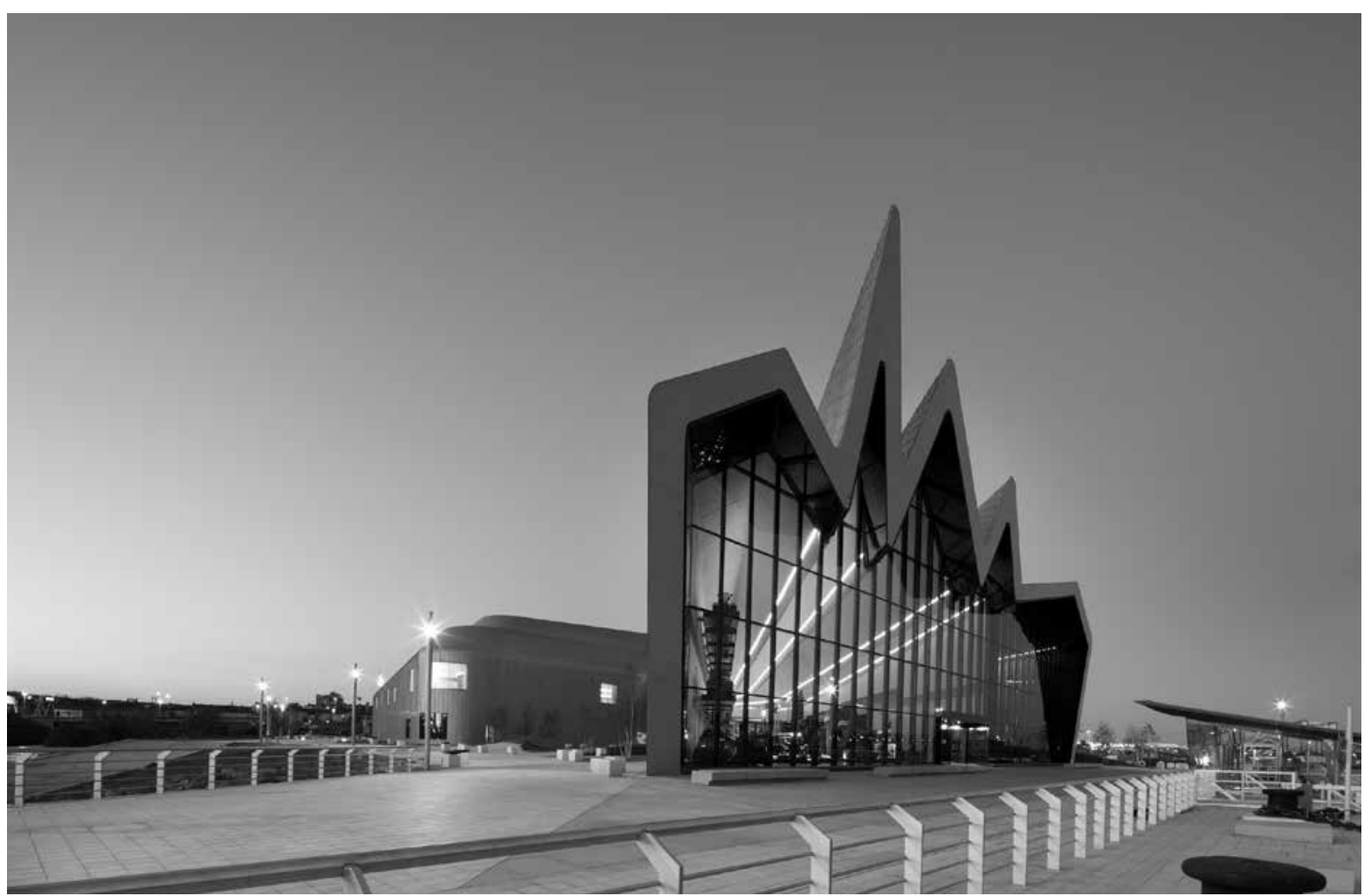

2 Glasgow Riverside Museum of Transport

home decoration, or architectural models were considered with seriousness and attention. Coupled with a privileged education that included mathematics and experimentation, her deeply sensual, intuitive, and aesthetic persona was able to thrive.

The experimental environment of the Architectural Association was the context where Hadid had grown professionally and where she was able to develop and express her creative powers. Contributing greatly to the AA's ethos, Hadid here met many of her future friends and collaborators such as Peter Rice, the engineer who encouraged Hadid's practice in the early stages of her career. Indeed, most people who worked in the practice often came from the AA and, in particular, from the Design Research Laboratory run by Hadid's main collaborator and later partner Patrik Schumacher.

Hadid's early architectural design - exemplified in the combination of uniquely-beautiful, critically-oriented, and highlyintelligent drawings - shone and sparkled from afar in the early 1980 attracting a fresh, new, modernist audience previously attracted by postmodernist approaches to form. Leading alternative magazines such as The Face enthusiastically covered their pages with Hadid's colourful drawings of the Hong Kong's Peak, the Irish Prime Minister's house or the new bridge for London designed in the Suprematist style of Malevich.

In 1988, Hadid's rise was further strengthened by her participation in the 'Deconstructivism in Architecture' exhibition curated by Philip Johnson and Mark Wigley for the Museum of Modern Art, New York. The show, followed by a London conference at the Tate where Hadid spoke, and a series of publications with the same name, unwittingly gave rise to a movement with which Hadid came to be associated at that time.

Following the ground-breaking but largely conceptual and experimental projects of the 1980 , the practice became fully established in the 1990 following the successful completion of the Vitra Fire Station in Weil am Rhein, Germany, (1993) - the first building that delivered the architectural expectations magically promised in the drawings. This coincided with realisation of a project in Berlin's IBA, on Stresemanstraße, that contributed to the international recognition of the growing practice.

These successes were followed by the landmark design competition project for Cardiff Opera House (1995), which was won but infamously never materialised. As a result, the endless unjustifiably harsh criticism from the establishment and the media generated headlines that reflected Cardiff's poor management of the competition. On a more positive note, the debate provided a focus for a larger discussion that extended into a more thoughtful, theoretical scrutiny about architectural form and the role of geometry.

This debate, which featured prominently at the Architectural Association, gained ground in the mid- and late-199os paving the way for a new approach to space and form-making in architecture. The condition of 'after geometry', and discourse related to the work of Zaha Hadid, Frank Gehry and Gregg Lynn, enabled novel conceptualisations of space and form, their newly-forged, dynamic, more fluid relationships, and their continuing dependence on representation that was now supported digitally.

In these respects, Zaha Hadid was led by her profound conviction and knowledge of architectural form grounded in experimentation in drawings, paintings and in a particular type of bas-relief paper modelling. Her involvement with the digital realm was the one of a smart observer who realised its potency. This meant that, in theoretical discussions, Hadid was more frequently joined by Patrik Schumacher who provided a focus 
for developing coherent arguments about the use of digitisation and its future contribution to the language of architecture. ${ }^{1}$ Nevertheless, it was Hadid's energy, propelled by her commanding intuition, that held it all together.

Following her deeply-held belief in design with an awareness of the complexities of architecture and life, Zaha Hadid accepted the digital realm with caution as she continued to sketch, draw, and make models of various kinds in order not to let her architecture fall into reductionist positions that would rely only on computer software. In that sense, the various design media used by the practice exemplify the dynamics of its transformation from the analogue to the digital, where the values of both technological models were appreciated and explored.

It is important not to overlook that the work of the Zaha Hadid Architects has been informed by numerous small, colourful, and ephemeral projects. These include: an exhibition design for The Great Utopia, about the constructivists, at The Guggenheim, New York (1992); a pavilion for Blueprint at the Interbuild exhibition (1995); a Habitable Bridge (1996); a stage design for the Pet Shop Boys tour in 1999 and; the 'Mind Zone' for London's Millennium Dome (1999). It is also important to remember larger, unrealised projects such as those for La Fenice, Venice (1996), the Prado (1996) and Reina Sofia (1999) museum extensions, Madrid, and the Grand Mosque in Strasbourg (2000) where new architectural language was tested for future projects. The features of the project for Strasbourg, for example, are echoed in the later Heydar Aliyev Centre in Azerbaijan's capital, Baku (2007-12).

The design and successful execution of Cincinnati's Rosenthal Centre of Contemporary Art in Ohio, US (1997-2003) was hugely important, as was the winning project for MAXXI: Italian National Museum of 21st Century Arts in Rome (1998-2010). The highly conceptual building and urban design proposal for Rome, whose geometry was based on fields theory, was materialised into a ground-breaking dynamic structure that sealed Zaha Hadid's reputation as a leading international architect.

The full weight of the new contribution to architectural design could be found at the
Phaeno Science Centre in Wolfsburg (1999-2005), a vastly innovative building where concerns for the city had to be met, and made to work in relation to a spaceshipcome-military-aeroplane-like structure that, due to its use of concrete, could be seen as an example of neo-brutalism. Working intensively with urban conditions characterises the schemes for: Hoenheim-North Terminus \& Car Park in Hoenheim, France (2001); the Bridge Pavilion in Zaragoza, Spain (2008); the Dongdaemun Design Plaza in Seoul South Korea

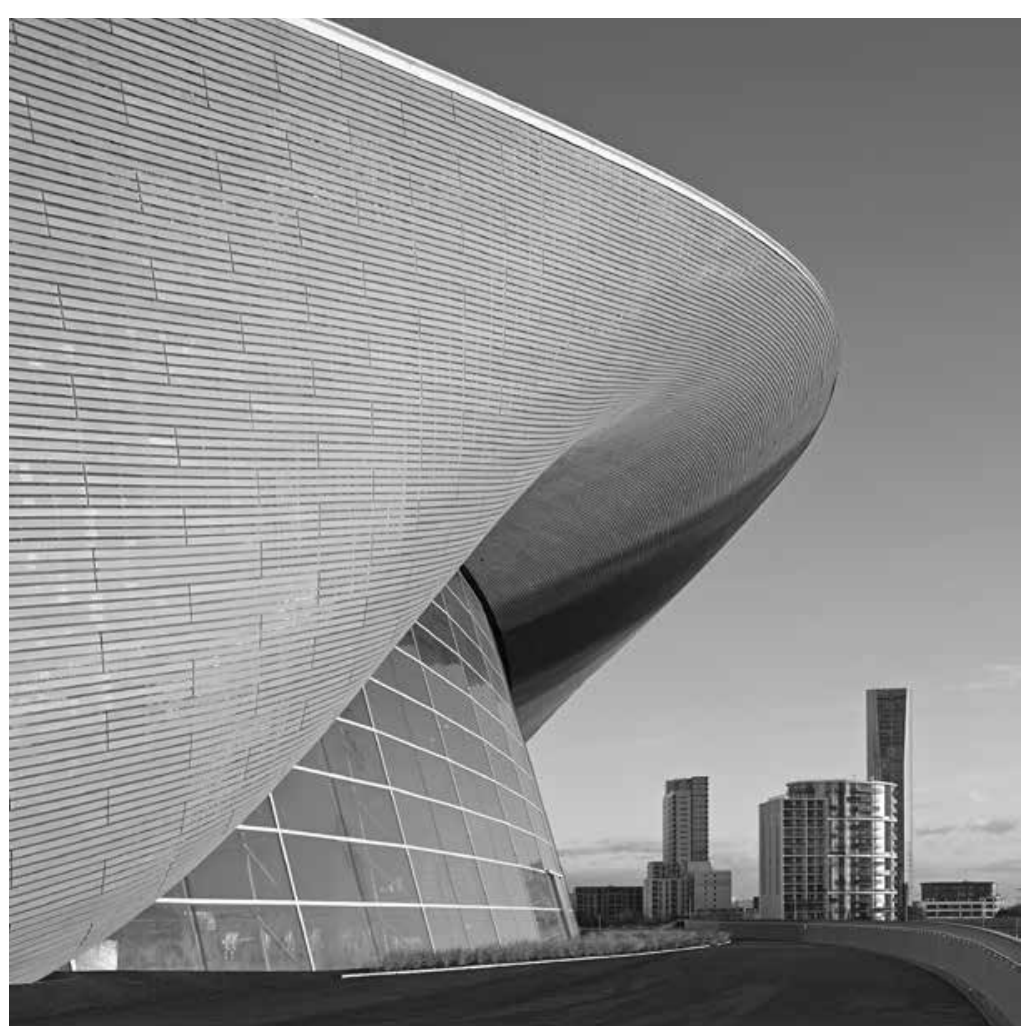

3 The London Aquatics Centre, designed for the 2012 Olympic Games, in so-called 'legacy mode' after banks of temporary seating were removed.

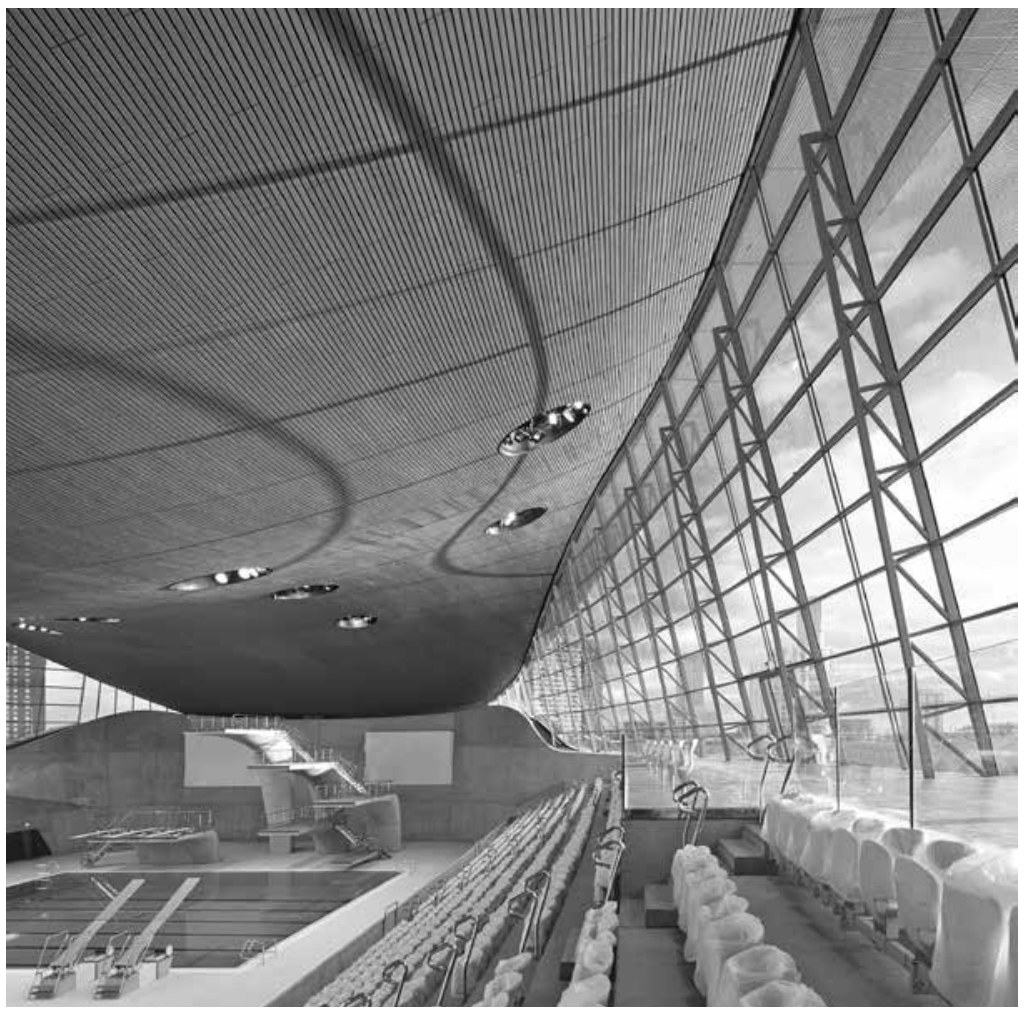

4 The interior of the London Aquatics Centre in so-called 'legacy mode'. 
(2007-14). And buildings that imaginatively forged their relationship to the environment include: Bergisel Ski Jump, Innsbruck, Austria (2002); Odrupgaard Museum extension in Denmark (2001-5); BMW Central Building in Leipzig, Germany (2006); and Maggie's Centre at the Victoria Hospital, in Kirkcaldy, Scotland (2006).

These many successes abroad led to Hadid's belated appreciation in the United Kingdom. When the 2012 Olympic Games were announced, a contribution from the extraordinary laboratory of Zaha Hadid Architects (ZHA) was widely anticipated. It appeared in the form of a fluid and elegant building for the Aquatic Centre on the Olympic Park at Stratford. With a school, the Evelyn Grace Academy in Brixton (2010), and the Serpentine Sackler Gallery in Hyde Park (2009-13), the Aquatic Centre makes a series of ZHA contributions to the architecture of the UK's capital. The impact of the Glasgow Riverside Museum (2004-11), on the shores of River Clyde, was an important contribution to the regeneration of this great postindustrial Scottish city.

What followed appears like plain sailing in the context of global success, resulting in buildings such as: the Skyscraper in the Euroméditerranée business district of Marseille (2005-10); the monumental Guangzhou Opera House, China (2005-10); the Pierresvives Building, Montpellier, France (2002-12); Heydar Aliyev Cultural Centre, Baku, Azerbaijan (2012); curvilinear asymmetric skyscrapers in Wangjing SOHO, Beijing (2009-14); the Innovation Tower for Hong Kong Polytechnic, Hong Kong, (2013); and Issam Fares Institute for Public Policy and International Affairs, Beirut (200614). Some designs were controversial and not considered feasible, such as the one for Tokyo's 2020 Olympic stadium. A testing of the limits of feasibility is evident in urban design proposals as well, such as the visionary but huge scale regeneration project for Kartal Pendik, Istanbul (2006).

It was 'very Zaha' to always test the limits: conceptual, structural, functional, aesthetic, communicational, and personal. She marvelled in pushing the boundaries and frontiers of human achievement. This was pursued not merely to provoke, but to gain new ground and new knowledge as well as to demonstrate that this was possible. In that sense, her practice - although often perceived as apparently chaotic - was a truly innovative laboratory that developed beyond the conceptual. This drive towards the inventive and experimental matched with a deep-seated willingness to see her projects constructed: the reason why Hadid went through the pain of arduous global travelling and project management. This life was often far less glamorous and more demanding than it seemed and, with hindsight, we could speculate about the toll it must have taken on Hadid's health.

The legacy of Zaha Hadid is there and it is living. Her practice, under Patrik Schumacher's guidance and the custody of faithful partners and colleagues such as Woody Yao and others, has all the chances to continue to thrive, despite the changes that will inevitably happen. Her masterful buildings, drawings, models, objects, and fashion items now stand as a global legacy. As the Turkish minister remarked, introducing Hadid to the pop starstyle audience of thousands of young architects and students at the International Union of Architects (UIA) Congress in 2005, Hadid surpassed all her contemporaries so he had to go back in history to compare her to the legendary Mimar Sinan (14891588), the architect of the Süleymaniye Mosque in Istanbul, concluding that she surpassed him too.

Regardless of the fact that Hadid did not like to call herself a woman architect or a feminist, she has become a feminist figure. Thousands of women architects across the world, such as the Chinese friend I mentioned at the beginning, felt the loss of Zaha Hadid. A profound pain that has been shared by many could only be explained by the fact that the space once occupied by this imaginative, flamboyant, creative, and elegant woman became empty and hence undefended. Zaha Hadid was the powerful guardian of this place and thus, by implication, acted as an invisible shield for numerous women in a male-dominated profession, where women are still paid and credited less than their male counterparts. Despite Zaha
Hadid's many accolades including the Pritzker Architecture Prize (2004), two RIBA Stirling Prizes (2010 and 2011), becoming a Dame (2012), and the RIBA Gold Medal (2015) - she did not, according to her own admission, feel part of the establishment. 'As a woman in architecture you're always an outsider. It's OK, I like being on the edge.'

Zaha Hadid, architect

(b. 31 October 195o, Baghdad, Iraq, d. 31 March 2016, Miami, Florida, US) is succeeded by her practice ZHA and many ongoing projects.

GORDANA FONTANA-GIUSTI

Gordana Fontana-Giusti is Professor of Architecture and Urban Regeneration at the University of Kent. Her Zaha Hadid Complete Works, with Patrik Schumacher, was published by Thames and Hudson and Rizzoli in 2004 and has been translated into three languages.

\section{Notes}

1. Patrik Schumacher, Digital Hadid: Landscape in Motion (Basel: Birkhauser, 2003).

\section{Illustration credits}

arq gratefully acknowledges:

Hufton + Crow, 3-4

Brigitte Lacombe, 1

Alan McAteer / McAteer Photograph, 2 